УДК 342.9: 347.97/.99

DOI https://doi.org/10.32844/2618-1258.2019.3-1.17

ВОЛКОВА Л.М.

\title{
ПУБЛІЧНЕ АДМІНІСТРУВАННЯ АДВОКАТУРИ УКРАЇНИ
}

Мета статті полягає в тому, щоб на базі дослідження обгрунтованих позицій вчених-юристів, нормативно-правової бази розкрити публічне адміністрування адвокатури України. В статті з'ясовано, що адвокатура як об'єкт адміністративно-правового забезпечення - це незалежна, правова, специфічно-професійна інституція, що взаємодоповнюється, координується та співпрацює 3 державою для створення гарантуючого механізму захисту прав, свобод та законних інтересів осіб через надання правової допомоги, що обумовлює реалізацію публічного адміністрування адвокатури для правової, кадрової та організаційної підтримки цієї інституційної складової в суспільстві.

Наголошено, що адвокатська діяльність є досить широкою за своєю природою, тому суспільні відносини, які виникають, змінюються або припиняються безпосередньо у зв'язку із здійсненням завдань і функцій державного управління по керівництву господарською, соціально-культурною і адміністративно-політичною сферами здійснюється публічно-правовими методами та підлягає регулюванню адміністративним правом. Визначено, що публічне адміністрування адвокатури має такі особливості: здійснюється різними за функціональним та право визначальними складом суб'єктами (органи юстиції, інші органи виконавчої влади, адвокатським врядуванням); реалізується шляхом використання специфічних елементів механізму правового регулювання, основним 3 яких $є$ норма права; за змістом $€$ стабільною, комплексною, системною, цілеспрямованою та координуючою діяльністю; метою є створення співпраці між адвокатурою та державою для забезпечення права кожного на правову допомогу та судовий захист.

Зроблено висновок, що публічне адміністрування адвокатури України - це особливий вплив державної влади на самостійний, незалежний та специфічний інститут громадянського суспільства (адвокатуру), що здійснюється спеціальними суб'єктами судово-виконавчої адміністрації для правового, організаційного, інформативного забезпечення адвокатів, кадрового наповнення адвокатури, розвитку координації і співпраці держави з адвокатурою з метою реалізації права кожного на правову допомогу і судовий захист.

Ключові слова: адвокатура, адміністративно-правове забезпечення, органи судочинства, правові засоби, правосуддя, прокуратура, публічне адміністрування, суд.

The purpose of the article is to reveal the public administration of the Bar of Ukraine on the basis of research of substantiated positions of legal scholars and legal framework. In the article it is found out that the bar is an object of administrative and legal support - it is an independent, legal, specific-professional institution, which complements, coordinates and cooperates with the state to create a guaranteeing mechanism of protection of the rights, freedoms and legal interests of persons by providing legal assistance, which stipulates the realization of public administration of the bar for legal, personnel and organizational support of this institutional component in society.

It is emphasized that advocacy is quite broad in nature, therefore, public relations that arise, change or terminate directly in connection with the implementation of tasks and functions of public administration in the management of economic, socio-cultural and administrative-political spheres are carried out by public law, methods and is governed by administrative law. It is determined that the public administration of a lawyer has the following features: it is carried out by different functional and law-determining entities (bodies of justice, other executive bodies, advocacy); implemented through the use of

(с) ВОЛКОВА Л.М. - здобувач (Науково-дослідний інститут публічного права) 
specific elements of the mechanism of legal regulation, the main of which is the rule of law; in content, it is stable, comprehensive, systematic, purposeful and coordinating; the aim is to create cooperation between the bar and the state to ensure everyone's right to legal aid and judicial protection.

It is concluded that public administration of the Ukrainian Bar is a special influence of the state power on an independent, independent and specific institute of civil society (bar), which is carried out by special subjects of the judicial and executive administration for legal, organizational, informative provision of lawyers, staffing, development of coordination and cooperation of the state with the bar in order to realize everyone's right to legal assistance and judicial protection.

Key words: advocacy, administrative and legal support, organs of justice, legal means of justice, prosecutors, public administration, justice.

Актуальність теми. Незалежний інститут адвокатури є складником будь-якого громадянського суспільства. Специфіка інституту адвокатури полягає в захисті двох абсолютно різних інтересів - приватного та публічного. Тобто, діяльність органів адвокатури в сфері публічного права, в цілому статус адвокатури як інституції громадянського суспільства, вказує на необхідність адміністративного впливу в функціонуванні адвокатури.

Публічне адміністрування адвокатури в Україні є відносно недослідженою площиною, а реформування адвокатури та запровадження євро стандартів в діяльності адвокатів підкреслюють актуальність наукових викликів у цій сфері.

Огляд останніх досліджень. Питанням публічного адміністрування адвокатури України займалися такі вчені як Н. Бакаянова,А. Бірюкова, В. Бойко, А. Борко, В. Галунько, М. Закурін, А. Іванищук, Р. Ігонін, В. Куценко, Н. Меєрович, І. Орловська, Т. Плугатар, І. Прошутя, С. Циганок, С. Чернявський, С. Шкребець та інші.

Проте, реформування публічних та приватних інституцій, що виконують завдання правової держави, в тому числі і адвокатури, вплинуло на зміну правовідносин, зокрема і в площині публічного адміністрування адвокатури, що зумовлює потребу в нових дослідженнях та наукових викликах.

Мета статті полягає в тому, щоб на базі дослідження обгрунтованих позицій вчених-юристів, нормативно-правової бази розкрити публічне адміністрування адвокатури України.

Виклад основних положень. Відповідно до ст. 2 Закону України «Про адвокатуру та адвокатську діяльність» від 5 липня 2012 р. № 5076-VI адвокатура України - це недержавний самоврядний інститут, що забезпечує здійснення захисту, представництва та надання інших видів правової допомоги на професійній основі, а також самостійно вирішує питання організації і діяльності адвокатури у встановленому законом порядку [7].

I. Орловська переконана, що адвокатська діяльність є об'єктом адміністративно-правового регулювання і розглядається, як система суспільних відносин, які виникають щодо здійснення захисту, представництва та надання інших видів правової допомоги клієнту (фізична або юридична особа, держава, орган державної влади, орган місцевого самоврядування) в інтересах яких здійснюється адвокатська діяльність, які врегульовуються нормами адміністративного права 3 метою забезпечення охорони й захисту прав та законних інтересів громадян та юридичних осіб, дотримання балансу публічних інтересів фізичних і юридичних осіб, держави й суспільства в цілому [6, с. 427].

$€$. Шкребець вказує, що адвокатура виступає одночасно як партнер держави, яка взяла на себе зобов'язання забезпечити право громадян на кваліфіковану юридичну допомогу. Як гарантуючий механізм держава використовує інститут адвокатури. Тим самим на адвокатуру покладаються особливі суспільні функції. В цьому якраз і полягає публічний характер адвокатської діяльності. Як громадський інститут адвокатура діє на певних принципах (законності, лояльності до клієнта, дотримання адвокатської етики, незалежності, самоврядності, корпоративності, рівноправності адвокатів, професіоналізму), гарантує громадянам право на кваліфіковану юридичну допомогу [10, с. 80-85].

А. Бірюкова вказує, що адвокатура в умовах глобалізації постає не просто як незалежна правозахисна інституція чи стійкий професійний осередок, спільнота, що об'єднана загальними цінностями, інтересами та нормами поведінки. У широкому сенсі адвокатура - це також унікальний комунікативний феномен, що є виразом взаємовідносин держави та суспільства, і показники 
якого визначають їх правовий клімат. Саме ця особливість обумовлює ії̈ приналежність до громадянського суспільства, що нині характеризує стан взаємодії соціуму та держави, слугуючи проявом процесу глобалізації [2, с. 402].

С. Чернявський вказує, що адвокатська діяльність $є$ досить широкою за своєю природою, тому суспільні відносини, які виникають, змінюються або припиняються безпосередньо у зв'язку із здійсненням завдань і функцій державного управління по керівництву господарською, соціально-культурною і адміністративно-політичною сферами здійснюється публічно-правовими методами та підлягає регулюванню адміністративним правом [8, с. 86-90].

Таким чином, адвокатура як об'єкт адміністративно-правового забезпечення - це незалежна, правова, специфічно-професійна інституція, що взаємодоповнюється, координується та співпрацює з державою для створення гарантуючого механізму захисту прав, свобод та законних інтересів осіб через надання правової допомоги, що обумовлює реалізацію публічного адміністрування адвокатури для правової, кадрової та організаційної підтримки цієї інституційної складової в суспільстві.

Сучасна адвокатура є невід’ємним і необхідним елементом механізму реалізації судової влади, яка, своєю чергою, є функцією держави. Публічний характер адвокатури зумовлюється ії питомою вагою у забезпеченні державою, покладеного на неї обов'язку щодо судового захисту прав, свобод та інтересів громадян. Інакше кажучи, адвокатура, якій притаманні всі риси інституту громадянського суспільства, органічно «вплітається» в механізм реалізації державної влади [2, c. 158$]$.

Як інститут громадянського суспільства, адвокатура регулюється зі сторони державою, це цей процес називається «публічним адміністрування», тому надалі варто розкрити поняття правової категорії «публічне адміністрування адвокатури». Вченими-адміністративістами встановлено, що публічне адміністрування як форма реалізації публічної влади - це адміністративна діяльність суб'єктів публічної адміністрації, яка є зовнішнім виразом реалізації завдань (функцій) виконавчої влади, що здійснюється з метою задоволення публічного інтересу й негативно відмежовується від законодавчої судової та політичної діяльності [3, с. 18].

Поняття «публічне адміністрування адвокатури» не визначено сучасною наукою адміністративного права, є дещо суміжні та тотожні категорії, зокрема, С. Чернявський вказує, що адміністративно-правове регулювання адвокатської діяльності можна визначити як сукупність основоположних засобів (норм права, правових відносин, актів тлумачення і застосування правових норм та ін.) державного впливу на суспільні відносини з метою забезпечення охорони й захисту прав та законних інтересів громадян та юридичних осіб та публічного інтересу держави і суспільства, що характеризується наявністю специфічного предмета, методів, типів та стадій впливу на суспільні відносини з метою їх урегулювання [8, с. 86-90].

Під поняттям «адміністративно-правове забезпечення діяльності адвокатури» $Є$. Шкребець пропонує розуміти діяльність уповноважених державою суб'єктів, що здійснюється на основі й на виконання приписів адміністративно-правових норм з метою реалізації закріплених у таких нормах гарантій діяльності адвокатури задля створення умов ефективного виконання завдань і функцій адвокатури $[9$, с. 5].

Отже, публічне адміністрування адвокатури - це особливий вплив державної влади на самостійний, незалежний та специфічний інститут громадянського суспільства (адвокатуру), що здійснюється спеціальними суб'єктами судово-виконавчої адміністрації для правового, організаційного, інформативного забезпечення адвокатів, кадрового наповнення адвокатури, розвитку координації і співпраці держави з адвокатурою з метою реалізації права кожного на правову допомогу і судовий захист.

Щодо безпосередніх особливостей публічного адміністрування адвокатури, то насамперед варто вказати про позицію Н. Бакаянової, відповідно до якої організаційні основи адвокатури полягають у формуванні двох блоків питань: 1) питань організації адвокатури як цілісного правового інституту (передовсім, питань адвокатського самоврядування, взаємовідносин адвокатури та держави, діяльності об’єднань адвокатів тощо); 2) питань організації адвокатської діяльності як певної сукупності адвокатів, об'єднаних спільною метою (зокрема, питання набуття особами статусу адвоката, форм організації адвокатської діяльності, професійної відповідальності адвоката не тільки перед клієнтом, а й перед адвокатською спільнотою) [1, с. 145-146].

А. Бірюкова вказує, що організація адвокатури у різних державах обумовлена загалом сукупністю таких чинників, як державний, адміністративно-територіальний і судовий устрій, а також історично сильні традиції певної спільноти/території, що у системному зв'язку зі спеціа- 
лізацією, яка є світовою тенденцією розвитку всіх «зрізів» адвокатури, формують оптимальну за певних умов модель цього правозахисного інституту правової системи. Спеціалізація в адвокатурі виражається в двох аспектах: організаційному (спеціалізація в системі корпоративного управління) та функціональному (спеціалізація в адвокатській діяльності).

Необхідність нормативного закріплення функціональної спеціалізації в адвокатурі України зумовлена не лише інтеграційними процесами, що їх спричиняє глобалізація, а й потребою гармонійного розвитку вітчизняної системи правосуддя, в якій існує та розвивається спеціалізація судів і суддів, що також є загальносвітовою тенденцією та кореспондується з європейськими стандартами здійснення судочинства. Законодавче запровадження функціональної спеціалізації в адвокатурі України (можливості набуття статусу спеціалізованого адвоката) вимагає системного підходу, який повинен охоплювати заходи, спрямовані на розробку типологізації спеціалізації адвокатів, умов і механізму набуття такого статусу, а також організаційний зріз, який передбачає зміну відповідних структур органів адвокатського самоврядування [2, с. 402-403].

Н. Меєрович вважає, що адвокати є представниками вільної професії, призначення яких полягає у тому, щоб забезпечувати потреби суспільства у професійній, кваліфікованій правовій допомозі. Адвокати перебувають між державою і громадянським суспільством,між владою та бізнесом,у силу цього в їх статусі присутня як комерційна,так і публічна складова. Так,з одного боку адвокати діють на платній основі,а отже однією з цілей осіб,що $є$ адвокатами чи прагнуть ними стати, є задоволення власних економічних потреб. А з іншого боку - сам інститут адвокатури сформувався не як комерційний, тобто,з метою отримання вигоди,а як засіб охорони та захисту прав, свобод і законних інтересів учасників суспільного життя, фізичних осіб та колективних суб'єктів. Адвокати хоча і не входять до складу державного механізму, тим не менш вони індивідуалізують по відношенню до конкретних випадків правозахисну та правоохоронну функцію держави. У зв'язку із чим,остання не тільки гарантує на рівні Конституції існування інституту адвокатури,але й усіляко сприяє його функціонуванню розвитку,встановлює суворі та чіткі критерії набуття статусу адвоката [5, с. 375].

С. Чернявський, грунтуючись на позиції О. Сщук, вказує, що специфічними ознаками адміністративно-правового регулювання адвокатської діяльності є наступні: це різновид соціального регулювання зі специфічними рисами, що характеризуються загальністю, обов'язковістю, конкретністю, державною примусовістю, стабільністю і прогнозованістю; це один із засобів державного впливу на суспільні відносини з метою забезпечення охорони й захисту прав та законних інтересів громадян та юридичних осіб та публічного інтересу суспільства і держави; являє собою систему, здійснюється за допомогою різноманітних елементів: норм права, правових відносин, актів тлумачення і застосування правових норм та ін., при цьому норма права є основою правового регулювання; характеризується наявністю специфічного предмету, методів, видів та стадій впливу на суспільні відносини $з$ метою їх урегулювання; предметом правового регулювання $\epsilon$ суспільні відносини, пов'язані з адвокатською діяльністю, здоров'я фізичних осіб та різних форм власності, впорядкування яких неможливо забезпечити без норм права; метод правового регулювання - це сукупність юридичних способів забезпечення охорони й захисту прав та законних інтересів громадян та юридичних осіб; до типів правового регулювання відносять загальний дозвіл та звільнення від заборони, до стадій - правова регламентація, конкретизація прав і обов'язків та фактична реалізація $[4 ; 8$, с. $86-90]$.

$€$. Шкребець визначено специфічні ознаки адміністративно-правового забезпечення діяльності адвокатури, зокрема: адміністративно-правове забезпечення є одним із важливих видів правозабезпечувальної діяльності держави, при цьому об'єктом адміністративно-правового забезпечення є професійні права і гарантії діяльності адвокатури України; здійснюється забезпечення на основі правотворчих та організаційних повноважень суб'єктів, чітко визначених у законодавстві України; процес забезпечення реалізується через особливий правовий механізм 3 метою забезпечення законності та правопорядку в суспільстві. адміністративно-правові заходи забезпечення адвокатської діяльності є різноманітними за своєю сутністю і природою. Їх зміст включає в себе компоненти дозволу, примусу та заохочення. У більшості випадків ці заходи мають імперативний, обов'язковий характер.

Зауважується, що чинним законодавством України встановлено широкий перелік адміністративно-правових заходів забезпечення адвокатської діяльності, а саме: а) формування бажання у особи займатись адвокатською діяльністю; б) допуску до складання кваліфікаційного іспиту; в) стажування; г) складання присяги адвоката України та отримання Свідоцтва про право на заняття адвокатською діяльністю, посвідчення адвоката України; г) підвищення кваліфікації; 
д) зупинення права на заняття адвокатською діяльністю; є) припинення права на заняття адвокатською діяльністю. Кожному етапу притаманний комплекс заходів, зміст яких визначається як особливостями законодавства, так і практикою функціонування адвокатури і органів адвокатського самоврядування [9, с. 15-16].

Висновки. Виходячи 3 положення Закону України «Про адвокатуру та адвокатську діяльність» від 5 липня 2012 р. № 5076-VI, суб’єктами, які здійснюють публічне адміністрування адвокатури в Україні є: Кабінет Міністрів України; органи юстиції (на чолі з Міністерством юстиції України, що в більшій мірі здійснюють публічне адміністрування адвокатури); інші органи виконавчої влади та місцевого самоврядування); органи адвокатського самоврядування (Національна асоціація адвокатів України, Вища кваліфікаційно-дисциплінарна комісія адвокатури, Вища ревізійна комісія адвокатури та інші.); громадські об'єднання.

Тобто, публічне адміністрування адвокатури має такі особливості: 1) здійснюється різними за функціональним та право визначальними складом суб' єктами (органи юстиції, інші органи виконавчої влади, адвокатським врядуванням); 2) реалізується шляхом використання специфічних елементів механізму правового регулювання, основним з яких є норма права; 3 ) за змістом $є$ стабільною, комплексною, системною, цілеспрямованою та координуючою діяльністю; 4) метою є створення співпраці між адвокатурою та державою для забезпечення права кожного на правову допомогу та судовий захист.

Отже, публічне адміністрування адвокатури України - це особливий вплив державної влади на самостійний, незалежний та специфічний інститут громадянського суспільства (адвокатуру), що здійснюється спеціальними суб'єктами судово-виконавчої адміністрації для правового, організаційного, інформативного забезпечення адвокатів, кадрового наповнення адвокатури, розвитку координації і співпраці держави з адвокатурою з метою реалізації права кожного на правову допомогу і судовий захист.

\section{Список використаних джерел:}

1. Бакаянова Н.М. Функціональні та організаційні основи адвокатури України : дис. ... д-ра юрид. наук: 12.00.10. Одеса, 2017. 395 с.

2. Бірюкова А.М. Правовий статус адвоката і адвокатури: вітчизняна модель у контексті процесів глобалізації: дис. ... д-ра юрид. наук : 12.00.10. Академія адвокатури України, Міністерство освіти і науки України, Київський національний університет імені Тараса Шевченка, Міністерство освіти і науки України. Київ, 2018. 508 с.

3. Галунько В., Діхтієвський П., Кузьменко О., Стеценко С. та ін. Адміністративне право України. Повний курс : підручник. Херсон : ОЛДІ-ПЛЮС, 2018. 446 с.

4. Єщук O.M. Адміністративно-правова охорона: теорія, практика та перспективи розвитку: дис. докт. юрид. наук 12.00.07. Відкритий міжнародний університет розвитку людини «Україна», 2017. 464 с.

5. Меєрович Н.А. Щодо адміністративно-правового статусу адвоката. Форум права. 2013. № 3. С. 372-375.

6. Орловська І.Г. Адвокатська діяльність як об'єкт адміністративно-правового регулювання. Форум права. 2013. № 2. С. 423-427.

7. Про адвокатуру та адвокатську діяльність: Закон України від 05.07.2012 № 5076-VI. Відомості Верховної Ради. 2013. № 27.

8. Чернявський С.С. Адвокатська діяльність у контексті адміністративного права. Актуальні проблеми права: теорія і практика. 2013. № 28. С. 86-90.

9. Шкребець Є.Ф. Адвокатура України: адміністративно-правове забезпечення діяльності на сучасному етапі: автореф. дис. канд. юрид. наук 12.00.07. Харківський національний університет імені В.Н. Каразіна, Харків, 2016. 20 с.

10. Шкребець С.Ф. Адміністративно-правовий статус адвокатури в Україні на сучасному етапі розвитку. Право і Безпека. 2015. № 2. С. 80-85.

11. Шкребець С. Шляхи вдосконалення адміністративного законодавства щодо забезпечення діяльності адвокатури в Україні. Підприємництво, господарство і право. 2016. № 2. C. 122-127. 